\title{
KEBIJAKAN PEMERINTAHAN DAERAH DALAM PENGELOLAAN KERUSAKAN LINGKUNGAN HIDUP DI KABUPATEN SIJUNJUNG DAN KABUPATEN DHARMASRAYA
}

\author{
Novina Deliza Eryani \\ Jurusan Ilmu Politik, Fisip, Universitas Andalas \\ Email : novinadeliza@gmail.com
}

\begin{abstract}
Abstrak
Meningkatnya angka kerusakan lingkungan hidup akibat ilegal logging, perkebunan kelapa sawit dan pertambangan illegal banyak terjadi di Kabupaten Dharmasraya dan Kabupaten Sijunjung. Tujuan penelitian ini adalah untuk melihat sejauh apa kebijakan publik telah menyelesaikan persoalan kerusakan lingkungan hidup. Penelitian ini menggunakan metode kualitatif studi kasus instrumental dengan menggunakan teori analisis kebijakan publik Thomas R Dye dan William N Dunn. Temuan dari penelitian ini adalah Kabupaten Sijunjung dan Kabupaten Dharmasraya telah mengeluarkan sejumlah peraturan, namun isi kebijakan tersebut hanya menjelaskan mengenai pengelolaan lingkungan hidup secara umum dan belum memuat secara mendalam mengenai pemecahan masalah terhadap kerusakan lingkungan hidup yang terjadi. Bukan hanya itu saja, analisis isi kebijakan ini juga menunjukkan bahwa ada sejumlah permasalahan yang belum termuat dalam kebijakan-kebijakan yang dikeluarkan oleh Kabupaten Sijunjung dan Kabupaten Dharmasaraya. Salah satunya berkaitan dengan pemindahan kewenangan dari Pemerintahan Daerah Kabupaten kepada Pemerintahan Provinsi terkait pengelolaan lingkungan hidup. .
\end{abstract}

Kata kunci : Kebijakan ; Lingkungan Hidup ; Pemerintahan Daerah

\begin{abstract}
Abstrack
The increasing number of environmental damage due to illegal logging, oil palm plantations and illegal mining has often occurred in Dharmasraya and Sijunjung districts. The purpose of this research is to see to what extent public policies have solved the problem of environmental damage. This research uses a qualitative method of instrumental case study using the theory of public policy analysis by Thomas $R$ Dye and William N Dunn. The findings of this study are that Sijunjung and Dharmasraya districts have issued a number of regulations, but the contents of these policies only explain environmental management in general and do not contain in-depth solutions to problems with environmental damage. Not only that, the analysis of the content of this policy also shows that there are a number of problems that have not been included in the policies issued by Sijunjung and Dharmasaraya districts. One of them is related to the transfer of authority from the Regency Regional Government to the Provincial Government regarding environmental management.
\end{abstract}

Keywords: Policy ; Environment ; Regional Government

\section{PENDAhuluan}

Pemerintahan daerah adalah penyelenggaraan urusan pemerintahan oleh pemerintah daerah dan DPRD menurut asas otonomi dan tugas pembantuan dengan prinsip otonomi yang seluas-luasnya dalam sistem dan prinsip Negara Kesatuan Republik Indonesia. Sekarang pemerintahan daerah tidak lagi hanya menjadi pelaksana operasional kebijakan-kebijakan yang telah ditetapkan oleh pemerintahan pusat, tetapi lebih diharapkan 
sebagai agen penggerak pembangunan di tingkat daerah/lokal. Demokrasi-ekonomi di tingkat nasional akan bergerak ke arah yang lebih baik apabila tatanan, instrumen, dan konfigurasi kearifan serta kesantunan demokrasi-ekonomi lokal lebih dulu terbentuk. Hal ini membuat sebuah kebijakan yang dibuat oleh pemerintahan daerah dapat terasa lebih dekat oleh masyarakat di tingkat lokal itu sendiri. Thomas R Dye mendefinisikan kebijakan publik sebagai whatever government choose to do or not to do (apapun yang dipilih pemerintah untuk dilakukan atau untuk tidak dilakukan). ${ }^{1}$ Definisi ini menekankan bahwa kebijakan publik adalah mengenai perwujudan "tindakan" dan bukan merupakan pernyataan keinginan pemerintahan atau pejabat publik semata. Kebijakan yang dibuat oleh pemerintahan tentunya akan berdampak pada kehidupan masyarakat. kebijakan itu juga berasal dari keluhan-keluhan masyarakat akan sebuah permasalahan, misalnya permasalahan kerusakan lingkungan yang terjadi.

Indonesia ialah negara yang menyimpan berbagai potensi dari hasil bumi yang begitu melimpah, baik yang dapat diperbaharui maupun yang tidak dapat diperbaharui. Sebagaimana diketahui bahwa bumi air dan kekayaan alam yang terkandung di dalamnya dikuasai oleh Negara dan dimanfaatkan sepenuhnya untuk kepentingan rakyat. ${ }^{2}$ Potensi yang dimiliki oleh Indonesia seharusnya dapat dimanfaatkan dengan baik dan masyarakat begitupun pemerintah bertanggungjawab akan hal itu. Beberapa tahun terakhir, Indonesia mengalami banyak persoalan, salah satunya terjadi banyak kerusakan lingkungan yang diakibatkan oleh berbagai hal. Sejumlah persoalan lingkungan masih menjadi pekerjaan rumah yang membutuhkan penyelesaian. Menurut survei litbang Koran Sindo ${ }^{3}$ ada beberapa persoalan yang menyumbang kerusakan lingkungan, di antaranya permasalahan sampah, kerusakan ekosistem laut dan daerah aliran sungai hingga pada kerusakan hutan, kerusakan tanah dan seterusnya. Kebijakan mengenai pengelolaan lingkungan hidup ialah UU No 32 Tahun 2009 tentang Pengelolaan dan Pengendalian Lingkungan Hidup. Kebijakan yang mengurus masalah pertambangan ialah UU No 4 Tahun 2009 tentang Pertambangan Mineral dan Batubara. Sedangkan, kebijakan untuk mengurusi kehutanan ialah UU No 41 Tahun 1999 tentang Kehutanan. Indonesia menerapkan prinsip otonomi daerah, artinya pemerintahan daerah punya wewenang untuk mengurus rumah tangganya sendiri. Wewenang tersebut diatur lebih lanjut dalam UU No 23 Tahun 2014 tentang Pemerintahan Daerah.

\footnotetext{
${ }^{1}$ Irfan, Islamy, Prinsip- prinsip Perumusan Kebijaksanaan Negara.(Jakarta: Bumi Aksara. 2009) Hal. 19 ${ }^{2}$ UUD 1945Pasal 33 ayat 2

${ }^{3}$ Diambil dari Koran Sindo "Problem Besar di Indonesia" https://nasional.sindonews.com/read/1302781/15/10-problem-besar-lingkungan-di-indonesia-1525347778, diakses pada tanggal 11 Mei 2019 Pkl 19.30 WIB
} 
Kabupaten Sijunjung merupakan salah satu Kabupaten di Sumatera Barat. Di Kabupaten ini banyak ditemukan aktivitas-aktivitas yang merusak linngkungan hidup. Aktivitas tersebut seperti Illegal Logging, perkebunan kelapa sawit hingga pertambangan. Menurut pemberitaan $\mathrm{KBR}^{4}$ mengatakan ada aktivitas illegal loging yang keluar dari Hutan Aia Amo setiap harinya mencapai 15 hingga 30 truk/hari. Menurut pemberitaan tersebut warga mengalami kekhawatiran. Illegal logging sudah merusak sumber air bersih, sumber air untuk pertanian, dan ancaman bencana akibat penebangan hutan tersebut. Bukan hanya pertambangan batu bara, pertambangan emas juga menjadi aktivitas yang menyumbang kerusakan lingkungan yang cukup besar di Kabupaten Sijunjung. Di Kabupaten Sijunjung ada sekitar 548 hektare persawahan sudah dikonversi menjadi pertambangan emas. Penambangan emas di Kabupaten Sijunjung sebenarnya sudah dimulai sejak lama. Persolan mulai muncul salah satunya ialah mengenai reklamasi lahan bekas tambang atau pemulihan lahan bekas pertambangan liar atau tanpa izin.

Sama seperti Kabupaten Sijunjung, Kabupaten Dharmasraya juga mengalami kerusakan lingkungan yang cukup besar. Permasalahan kerusakan lingkungan ini disebabkan oleh beberapa hal. Seperti Ilegal Logging/Pembalakan liar, perkebunan kelapa sawit hingga pertambangan. Illegal logging/pembalakan liar Seperti yang dikatakan oleh Wakil Bupati Dharmasraya ${ }^{5}$ bahwa illegal loging adalah salah satu permasalahan yang terkatagori luar biasa. Ia juga mengatakan bahwa Ratusan meter kayu gelondongan sekurang kurangnya dikuras dari bumi kabupaten Dharmasraya setiap malam. Pertambangan emas juga merupakan aktivitas yang marak terjadi di Kabupaten Dharmasraya. Menurut KKI Warsi di Dharmasraya tercatat areal penambangan emas liar seluas 1340 ha. Lahan rusak ini tentu akan mengakibatkan sejumlah persoalan seperti kualitas lingkungan yang menurun drastis, rusaknya ekosistem hingga dapat terjadinya bencana ekologi.

Permasalahan lingkungan sudah ada sejak lama. Di Kabupaten Sijunjung dan Kabupaten Dharmasaraya, permasalahan tersebut didominasi terjadi pada sektor pertambangan dan kehutanan. Hal ini tentu menjadi tantangan bagi Pemerintahan Kabupaten mengingat kewenangan untuk mengelola sektor pertambangan dan kehutanan sudah dialihkan kepada Pemerintahan Provinsi. Walaupun demikian, Pemerintahan Kabupaten tetap memiliki wewenang dalam mengelola lingkungan hidup di daerahnya. Hal ini membuat Pemerintahan Kabupaten tidak bisa lepas tangan terhadap kerusakan lingkungan hidup yang terjadi, termasuk yang ada pada sektor pertambangan dan kehutanan. Meningkatnya angka kerusakan lingkungan hidup akibat illegal logging,

\footnotetext{
${ }^{4}$ Diambil dari KBR "Penebangan Liar di Hutan Aia Amo diprotes" https://kbr.id/nusantara/062016/peneban gan_liar_di_hutan_aia_amo_diprotes_warga/82686.html,diakses pada tanggal 12 Mei 2019 Pkl 19.00 WIB ${ }^{5}$ Diambil dari Harian Haluan. "Wabup Dharmasraya Sikat Ilegal loging” https://www.harianhaluan.com/news /detail/56350/wabup-dharmasraya-sikat-ilegal-login, diakses pada tanggal 11 Mei 2019 Pkl 22.00 WIB
} 
perkebunan kelapa sawit dan pertambangan ilegal di Kabupaten Dharmasraya dan Kabupaten Sijunjung ini, karena lambannya pemerintahan kabupaten dalam menyelesaikan permasalahan. Peneliti berasumsi bahwa ini terjadi karena tidak optimalnya kebijakan lingkungan hidup yang dikeluarkan oleh Kabupaten Sijunjung dan Kabupaten Dharmasaraya. Hal ini terjadi karena ada beberapa sektor yang kewenangannya tidak lagi dimiliki oleh Kabupaten. Maka dari itu muncul pertanyaan peneliti yang dijadikan sebagai rumusan masalah dalam penelitian ini: Mengapa k'ebijakan lingkungan hidup di Kabupaten Sijunjung dan Kabupaten Dharmasaraya dalam pengelolaan kerusakan lingkungan hidup tidak berjalan?

\section{Konsep Kebijakan Publik}

Robert Eyestone sebagaimana dikutip Leo Agustino mendefinisikan kebijakan publik sebagai "hubungan antara unit pemerintah dengan lingkungannya". Banyak pihak beranggapan bahwa definisi tersebut masih terlalu luas untuk dipahami, karena apa yang dimaksud dengan kebijakan publik dapat mencakup banyak hal. ${ }^{6}$ Menurut Woll sebagaimana dikutip Tangkilisan menyebutkan bahwa kebijakan publik ialah sejumlah aktivitas pemerintah untuk memecahkan masalah di masyarakat, baik secara langsung maupun melalui berbagai lembaga yang mempengaruhi kehidupan masyarakat. ${ }^{7}$ Sedangkan Thomas $\mathrm{R}$ dye mendefinisikan kebijakan publik sebagai "apapun yang dipilih oleh pemerintah untuk melakukan sesuatu atau tidak melakukan sesuatu". Menurut Dye, jika pemerintah memilih keputusan (berarti memilih sesuatu) untuk melakukan sesuatu maka harus ada tujuannya dan kebijakan negara itu harus meliputi semua "tindakan" pemerintah, jadi bukan semata-mata, merupakan pernyataan keinginan pemerintah atau pejabat pemerintah saja. Dan apa yang tidak dilakukan pemerintahpun termasuk kebijakan negara. Hal ini disebabkan karena bila pemerintah "tidak melakukan sesuatu" akan mempunyai dampak yang sama besarnya dengan apabila pemerintah "melakukan sesuatu". ${ }^{8}$

\section{Konsep Analisis Kebijakan Publik}

Menurut Dunn, analisis kebijakan adalah suatu aktivitas intelektual yang dilakukan dalam proses politik. Analisis kebijakan merupakan aktivitas menciptakan pengetahuan tentang dan dalam proses pembuatan kebijakan. Analisis kebijakan merupakan penelitian sosial terapan yang secara sistematis disusun dalam rangka mengetahui substansi dari kebijakan agar dapat diketahui secara jelas informasi mengenai masalah-masalah yang dijawab oleh kebijakan dan masalah-masalah yang mungkin timbul sebagai akibat dari

\footnotetext{
${ }^{6}$ Leo Agustino.2008.,Dasar-dasar Kebijakan Publik. Bandung: Alfabeta. Hal 8.

${ }^{7}$ Hesel Nogi Tangkilisan.2003.Kebijakan Publik Yang Membumi. Yogyakarta: Lukman Offset YPAPI. Hal 2

${ }^{8}$ M Irfan Islamy,2010. Kebijakan Publik. Jakarta: Universitas Terbuka. Hal 1.9
} 
penerapan kebijakan. Ruang lingkup dan metode analisis kebijakan umumnya bersifat deskriptif dan faktual mengenai sebab-sebab dan akibat- akibat suatu kebijakan. ${ }^{9}$

Penelitian kebijakan sedapat mungkin melihat berbagai aspek dari kebijakan agar dapat menghasilkan informasi yang lengkap. Informasi mengenai masalah-masalah yang dijawab oleh kebijakan serta masalah-masalah yang ditimbulkan dari penerapan kebijakan menjadi fokus dari analisis kebijakan. Rekomendasi yang dihasilkan dari proses penelitian kebijakan dapat berupa dukungan penuh terhadap kebijakan, kritik dan saran mengenai bagian mana dari kebijakan yang perlu diperbaiki, atau dapat juga berupa rekomendasi agar kebijakan tidak lagi diterapkan.

Informasi yang berkaitan dengan kebijakan berupa masalah kebijakan, masa depan kebijakan, aksi kebijakan, hasil kebijakan, dan kinerja kebijakan. Analisis kebijakan menggabungkan lima prosedur umum yang lazim dipakai dalam pemecahan masalah manusia, yaitu: definisi, prediksi, preskripsi, deskripsi dan evaluasi ${ }^{10}$. Masing-masing dari informasi kebijakan berkaitan dengan prosedur kebijakan.

\section{Konsep Kerusakan Lingkungan Hidup}

Lingkungan hidup diartikan sebagai kesatuan ruang dengan semua benda, daya, keadaan, dan makhluk hidup termasuk di dalamnya manusia dan perilakunya yang mempengaruhi kelangsungan kehidupan dan kesejahteraan manusia serta makhluk hidup lainnya. ${ }^{11}$ S.J McNaughton dan Larry L Wolf mengartikannya dengan semua factor eksternal yang bersifat biologis dan fisika yang langsung mempengaruhi kehidupan, pertumbuhan, perkembangan, dan reproduksi organisme. ${ }^{12}$ Bahaya yang senantiasa mengancam kelestarian lingkungan dari waktu ke waktu ialah pencemaran dan pengrusakan lingkungan hidup. Pencemaran Lingkungan Hidup adalah masuk atau dimasukkannya makhluk hidup, zat, energi, atau komponen lain kedalam lingkungan hidup oleh kegiatan manusia sehingga melampaui baku kerusakan lingkungan hidup. ${ }^{13}$ Perusakan Lingkungan Hidup adalah tindakan orang yang menimbulkan perubahan langsung atau tidak langsung terhadap sifat fisik, kimia, atau hayati lingkungan hidup sehingga melampaui kriteria baku kerusakan lingkungan hidup. ${ }^{14}$

\footnotetext{
${ }^{9}$ Ibid., Hal 95-97

${ }^{10}$ Dunn, PengantarAnalisis..., 17-21.

${ }^{11}$ Otto Soemarwoto.2001. Analisa Mengenal Dampak Lingkungan.. Yogyakarta: UGM Press.Hal. 18

${ }^{12}$ N.H.T. Siahaan.2004. Hukum Lingkungan Dan Ekologi Pembangunan. Jakarta: Erlangga. Hal. 4

${ }^{13}$ Pasal 1 ayat 14 UU No 32 Tahun 2009 Tentang Pengelolaan dan Pengandalian Lingkungan Hidup

${ }^{14}$ Pasal 1 ayat 16 UU No 32 Tahun 2009 Tentang Pengelolaan dan Pengandalian Lingkungan Hidup
} 


\section{METODE PENELITIAN}

Pendekatan yang digunakan dalam penelitian ini menggunakan pendekatan kualitatif. Pendekatan ini berguna untuk menjelaskan fenomena sosial yang ingin diteliti secara mendalam. Pendekatan Kualitatif merupakan prosedur penelitiaan, yang menghasilkan data deskriptif berupa kata-kata tertulis atau lisan dari orang-orang dan perilaku yang diamati. ${ }^{15}$ Selain itu, penelitian kualitatif adalah mengamati orang dalam lingkungan, berinteraksi dengan mereka dan menafsirkan pendapat mereka tentang dunia sekitar. Sedangakan tipe yang digunakan dalam penelitian ini adalah Studi Kasus Instrumental.

Penggunaan pendekatan dan tipe penelitian ini bertujuan agar peneliti bisa menjelaskan dan menggambarkan secara tertulis tentang fenomena yang peneliti angkat untuk disusun kedalam laporan penelitian yang kompleks dan efisien. Sehingga apa yang menjadi tujuan dari penelitian ini dapat terjawab dengan baik. Lokasi penelitian ini dilakukan di Kabupaten Sijunjung dan Kabupaten Dharmasraya. Unit analisis dalam penelitian ini adalah institusi, yaitu Pemerintahan Kabupaten di Sijunjung dan Dharmasraya. Teknik pengumpulan data menggunakan wawancara, dokumentasi dan observasi sedangkan pemilihan informan menggunakan purposive sampling. Teknik analisis data emik dan etik.Sedangkan untuk keabsahan data, peneliti menggunakan triangulasi sumber data.

\section{HASIL DAN PEMBAHASAN}

\section{Analisis Isi Kebijakan Pengelolaan Kerusakan Lingkungan Hidup di Kabupaten Sijunjung}

Peralihan kewenangan dalam UU No 23 Tahun 2014 Tentang Pemerintahan Daerah membawa sejumlah perubahan ke dalam Pemerintahan Kabupaten khususnya pada sektor yang dialihkan, yaitu pertambangan dan kehutanan. Salah satu perubahan tersebut ialah perubahan kebijakan pengelolaan kerusakan lingkungan hidup di tingkat Kabupaten. Sebelum peralihan kewenangan Pemerinatahan Kabupaten Sijunjung mengeluarkan beberapa kebijakan. Pertama, Peraturan Daerah Kabupaten Sijunjung Nomor 11 Tahun 2013 Tentang Perlindungan Dan Pengelolaan Lingkungan Hidup. Perlindungan dan Pengelolaan Lingkungan Hidup atau PPLH ini merupakan kebijakan yang dibuat oleh pemerintah daerah Kabupaten Sijunjung untuk menyelesaikan persoalan. Seperti yang dikatakan oleh Wakil Ketua DPRD Kabupaten Sijunjung:

"Respon pemerintah tentu begitu penting untuk menyelesaikan persoalan. Karena isu lingkungan untuk secara keseluruhan itu telah menjadi isu publik atau masalah

${ }^{15}$ Lexy J Maleong, 2004. Metodologi Penelitian Kualitatif.Bandung: PT Remaja Rosdakarya, Hal.3 
publik yang menyebabkan banyak hal. Maka dari itu diperlukan inisiatif dari DPRD bersama Bupati mencoba menginisiasi agar adanya peraturan yang lebih cocok untuk saat sekarang ini dalam menyelesaikan persoalan."16

Berikut beberapa hal yang dimuat dalam peraturan ini:

1. Perencanaan Melalui Rencana Perlindungan dan Pengelolaan Lingkungan Hidup (RPPLH)

2. Pemanfaatan Sesuai Dokumen Daya Dukung dan Daya Tampung Lingkungan Hidup

3. Pengendalian Pencemaran dan Kerusakan Lingkungan Hidup

4. Pemeliharaan

Dalam Kebijakan Perlindungan dan Pengelolaan lingkungan hidup Kabupaten Sijunjung ini telah didapatkan bagaimana peran Pemerintahan Daerah dalam pengelolaan lingkungan hidup di daerahnya. Namun, tertuangnya isi kebijakan ternyata tidak membuat kerusakan lingkungan hidup terselesaikan. Mulai dari perencanaan dan pemanfaatan, bahwa Kabupaten Sijunjung belum mampu menghadirkan perencanaan pengelolaan lingkungan hidup pada setiap sektornya. Ini terbukti dari belum adanya RPPLH Kabupaten Sijunjung. Begitupun pemanfaatan yang seharusnya berdasarkan perencanaan tentu akan terganggu sehingga membuat setiap kegiatan bahkan setiap sektor tidak terawasi dengan baik dalam mengelola lingkungan hidupnya. Dan hal ini dapat diidentifikasi bahwasanya ketidakoptimalan Kabupaten Sijunjung dalam menyelesaikan permasalahan kerusakan lingkungan hidup dimulai dari perencanaan yang belum jelas.

Kedua, Kabupaten Sijunjung mengeluarkan Peraturan Daerah Kabupaten Sijunjung Nomor 3 Tahun 2014 Tentang Pengelolaan Pertambangan Mineral dan Batu Bara. Dalam Peraturan ini mengemukakan adanya kewenangan Pemerintahan Daerah Kabupaten untuk menyelesaikan persoalan urusan pertambangan. Kewenangan tersebut, salah satunya Pembuatan Produk Hukum Daerah serta Pemberian IUP dan IPR, pembinaan, penyelesaian konflik masyarakat, dan pengawasan usaha pertambangan dan perizinan lainnya, dan lain sebagainya.

Peraturan Daerah No 3 Tahun 2014 ini telah memuat sejumlah pasal untuk mengatur mengenai aktivitas pertambangan. Hal ini bertujuan agar aktivitas-aktivitas pertambangan tidak muncul sebagai sesuatu yang merusak lingkungan hidup. Hal ini sejalan dengan konsep pembangunan berkelanjutan yang tidak hanya berorientasi pada pembangunan ekonomi tetapi juga memikirkan pelestarian dan perlindungan lingkungan hidup. Kebijakan yang dikeluarkan oleh pemerintahan Kabupaten Sijunjung ini adalah

\footnotetext{
${ }^{16}$ Wawancara dengan Walbandi, Wakil Ketua DPRD Kabupaten Sijunjung, di Kantor DPRD Sijujung, Pada tanggal 15 Agustus 2019
} 
kebijakan yang juga akan dan telah dipengaruhi oleh beberapa faktor termasuk salah satunya faktor lingkungan. Seperti yang diungkapkan oleh Dye bahwasanya lingkungan kebijakan memiliki peranan penting dalam sebuah sistem kebijakan. Dan Pemerintahan Kabupaten Sijunjung dalam hal ini tentu memiliki kewenangan dalam menghasilkan sebuah kebijakan pertambangan yang baik guna tetap terjaganya lingkungan hidup.

Setelah peralihan kewenangan ada beberapa perubahan kebijakan yang dilakukan oleh Pemerintahan Kabupaten Sijunjung. Pertama, Peraturan Daerah No 3 Tahun 2014 Tentang Pertambangan Mineral dan Batubara Sudah Tidak Berlaku Lagi. Dari hal tersbeut didapatkan bahwa Pemerintahan Kabupaten sudah tidak lagi mengurusi bidang pertambangan. Padahal, kerusakan lingkungan hidup masih tetap berada di tangan Kabupaten.

Kedua, Peraturan Bupati Sijunjung Nomor 78 Tahun 2018 Tentang Jenis Rencana Usaha Dan/Atau Kegiatan Yang Wajib Dilengkapi Dengan Upaya Pengelolaan Lingkungan Hidup.Peraturan ini masih berada pada pengurusan perizinan dan pengawasan terhadap pertambangan-pertambangan serta perkebunan-perkebunan besar. Padahal, aktivitas perusakan lingkungan hari ini mayoritas berasal dari aktivitas pertambangan emas ilegal. Peraturan seperti ini tentu belum menjawab dan menyelesaikan persoalan untuk pertambangan atau aktivitas lainnya yang tidak mempunyai izin. Pengawasan yang dilakukan oleh aktor terkait dalam peraturan ini juga mendapat kendala, karena hari ini pertambangan dan kehutanan perngurusannya berada di tangan provinsi. Dan Peraturan ini belum mengatur secara rinci mengenai pengawasan terhadap sektor pertambangan dan kehutanan. Hal ini membuat ketidaktahuan atau ketidakpahaman pelaku pelaksana dalam melakukan pengawasan yang tidak diatur secar rinci tersebut diaturan ini.

\section{Analisis Isi Kebijakan Pengelolaan Kerusakan Lingkungan Hidup di Kabupaten Dharmasraya}

Sama seperti Kabupaten Sijunjung, Peralihan kewenangan dalam UU No 23 Tahun 2014 Tentang Pemerintahan Daerah juga membawa sejumlah perubahan ke dalam Kebijakan Pemerintahan Kabupaten Dharmasraya. Salah satu perubahan tersebut ialah perubahan kebijakan pengelolaan kerusakan lingkungan hidup di tingkat Kabupaten. Sebelum peralihan kewenangan Kabupaten Dharmasraya mengeluarkan kebijakan untuk urusan pertambangan. Kebijakan tersebut dapat dilihat dalamPeraturan Daerah Kabupaten Dharmasaraya No 19 Tahun 2007 Tentang Pengelolaan dan Pengusahaan Pertambangan dan Energi. Peraturan Daerah ini adalah sebagai ketentuan pokok bagi Bupati dalam pengaturan, perizinan, pembinaan dan pengawasan pertambangan dan energi serta menciptakan iklim yang kondusif bagi terlaksananya pembangunan di sektor pertambangan dan energi yang berkelanjutan serta memberikan kepastian hukum kepada dunia usaha, 
masyarakat dan Pemerintah Daerah guna meningkatkan Pendapatan Daerah melalui upaya peningkatan nilai tambah.

Namun, setelah peralihan kewenangan Kabupaten dharmasraya mengeluarkan kebijakan-kebijakan baru. Pertama, Peraturan Daerah No 3 Tahun 2017 Tentang Pencabutan 4 Peraturan Daerah. Ini adalah tentang pencabutan sejumlah peraturan daerah salah satunya Perda tentang Pengelolaan dan Pengusahaan Pertambangan Mineral dan Energi. Dengan demikian, urusan pertambangan sudah tidak lagi menjadi kewenangan Pemerintahan Daerah Kabupaten. Kedua, Peraturan Daerah Kabupaten Dharmasraya Nomor 2 Tahun 2017 Tentang Perlindungan dan Pengelolaan Lingkungan Hidup. Kebijakan yang dikeluarkan oleh Kabupaten Dharmasraya untuk sektor lingkungan hidup ialah Peraturan Daerah Kabupaten Dharmasraya Nomor 2 Tahun 2017 tentang Perlindungan dan Pengelolaan Lingkungan Hidup. Perlindungan dan Pengelolaan Lingkungan Hidup atau PPLH ini merupakan kebijakan yang dibuat oleh pemerintah daerah Kabupaten Dharmasraya untuk menyelesaikan persoalan. Seperti yang dikatakan oleh Wakil Ketua Komisi II DPRD Kabupaten Dharmasraya:

"Karena isu lingkungan untuk secara keseluruhan itu telah menjadi isu publik atau masalah publik. Dan masalah publik ini telah mengakibatkan banyak hal mulai dari yang terlihat sampai yang tidak terlihat. Maka dari itu DPRD bersama Bupati mencoba menginisiasi agar adanya peraturan yang lebih cocok untuk saat sekarang ini dalam menyelesaikan persoalan." 17

Dari peraturan tersebut didapatkan beberapa hal yang perlu dilihat dalam menilai kebijakan lingkungan hidup di daerah ini, yaitu:

1. Perencanaan yang diwujudkan dalam Rencana Perlindungan dan Pengelolaan Lingkungan Hidup (RPPLH)

2. Pemanfaatan

3. Pengendalian

4. Pemeliharaan

5. Pengawasan

6. Penegakan Hukum

Namun, tertuangnya isi kebijakan pada Peraturan Daerah Kabupaten Dharmasraya ini ternyata tidak membuat kerusakan lingkungan hidup terselesaikan. Mulai dari perencanaan dan pemanfaatan, bahwa sama seperti Kabupaten Sijunjung, Kabupaten Dharmasraya juga belum mampu menghadirkan perencanaan pengelolaan lingkungan hidup pada setiap sektornya. Ini terbukti dari belum adanya RPPLH Kabupaten

${ }_{17}$ Wawancara dengan Syafril Ilyas, Wakil Ketua Komisi II DPRD Kabupaten Dharmasraya, di Gedung DPRD Kabupaten Dharmasraya pada tanggal 4 Juli 2019 
Dharmasraya. Begitupun pemanfaatan yang seharusnya berdasarkan perencanaan tentu akan terganggu sehingga membuat setiap kegiatan bahkan setiap sektor tidak terawasi dengan baik dalam mengelola lingkungan hidupnya. Dan hal ini dapat diidentifikasi bahwasanya ketidakoptimalan Kabupaten Dharmasraya dalam menyelesaikan permasalahan kerusakan lingkungan hidup dimulai dari perencanaan yang belum jelas.

Ketiga, Peraturan Bupati Dharmasraya Nomor 38 Tahun 2016 Tentang Tata Kelola Penyusunan Upaya Pengelolaan Lingkungan Hidup Dan Upaya Pemantauan Lingkungan Hidup Serta Surat Pernyataan Kesanggupan Pengelolaan Dan Pemantauan Lingkungan Hidup Di Kabupaten Dharmasraya. Peraturan ini memuat tentang penyusunan dokumen lingkungan hidup diantaranya:

1. Upaya Pengelolaan Lingkungan Hidup dan Upaya Pemantauan Lingkungan Hidup (UKL-UPL)

2. Surat Pernyataan Pengelolaan Lingkungan (SPPL)

Dari kebijakan tersebut dapat dilihat bahwa pemerintahan Kabupaten Dharmasraya masih kesulitan dalam melakukan pengawasan. Dalam sebuah fenomena atau permasalahan diperlukan kecakapan pemerintah dalam menyikapi fenomena atau masalah tersebut. Kecakapan pemerintah tersebut mendorong agar terciptanya sebuah kebijakan yang mampu menyelesaikan persoalan. Pemerintah Kabupaten Dharmasraya telah memilih untuk memilih melakukan sesuatu dalam menyelesaikan permasalahan kerusakan lingkungan hidup yang terjadi di daerahnya.

\section{Evaluasi Isi Kebijakan Terhadap Pengelolaan Kerusakan Lingkungan Hidup di Kabupaten Sijunjung dan Kabupaten Dharmasraya}

Ada beberapa hal yang perlu dilihat dalam mengevaluasi isi kebijakan publik. Pertama, Isi Kebijakan Belum Mampu Mengatasi Kegiatan Merusak Lingkungan Hidup Telah Bertahun-tahun Lalu Dilakukan. Kabupaten Sijunjung dan Kabupaten Dharmasraya adalah sebuah Kabupaten yang memiliki sejarah yang panjang terkait dengan aktivitas yang dapat menyebabkan kerusakan. Kegiatan yang telah ada bertahun-tahun lalu ini tentu erat kaitannya dengan Lingkungan sosial dan ekonomi yang ada dalam masyarakat. Hal demikian dapat dilihat dari aktivitas perusakan lingkungan yang telah menjadi kebiasaan dan lapangan pekerjaan bagi masyarakat. Seperti yang diungkapkan oleh Wakil Ketua DPRD Kabupaten Sijunjung, bahwasanya:

"Lingkungan sosial dan ekonomi yang mempengaruhi kebijakan lingkungan hidup ialah aktivitas yang sering menyebabkan kerusakan itu sudah menjadi lapangan pekerjaan bagi masyarakat. dan itulah yang menyebabkan betapa sulitnya untuk menghentikan kegiatan tersebut. Dari sinilah kami selaku pemerintahan masih terus 
mencoba menemukan alternatif agar semua pihak bisa dapat diuntungkan dan tidak rugi" 18

Dari wawancara di atas dapat dilihat bahwa memang benar aktivitas tidak berizin ini telah lama menjadi lapangan pekerjaan masyarakat. Hal ini dapat dilihat bahwa diperlukannya kebijakan yang bisa menyesuaikan dengan lingkungan masyarakat. Bukan hanya itu saja, kebijakan juga perlu dapat dipahami dengan baik oleh para pelaku yang terlibat dalam kebijakan. Lingkungan sosial dan ekonomi inilah yang perlu dilihat pemerintah agar menerbitkan peraturan atau adanya larangan harusnya memikirkan hal ini juga. Seorang masyarakat yang pekerjaan atau lumbung nafkahnya ada di penambangan dan pembalakan harus menjadi poin penting pemerintah juga dalam menerbitkan aturan. Dan kebijakan yang dikeluarkan akan lebih bisa diterima dan sesuai dengan yang diharapkan oleh pihak manapun.

Kedua, isi Kebijakan Hanya Bertumpu Pada Pencegahan Belum Pada Pemulihan. Kabupaten Sijunjung dan Kabupaten dharmasraya adala dua Kabupaten yang mengalami kerusakan lingkungan hidup yang cukup tinggi. Hal ini dikarenakan banyaknya aktivitas perusakan lingkungan yang telah dilakukan bertahun-tahun lalu. Hal tersebut didapatkan bahwa kegiatan yang telah dilakukan bertahun-tahun tentu akan menyebabkan kerusakan yang jika dibiarkan akan semakin membesar. Untuk itu diperlukannya pemulihan lahanlahan rusak agar tidak terjadi bencana. Program-program pemulihan akibat kerusakan memang sebuah tantangan bagi daerah agar pembangunan berperspektif lingkungan hidup dapat terealisasi dengan baik. Namun, kebijakan yang dikeluarkan oleh Pemerintahan Daerah belum menyentuh pembulihan terhadap kegiatan-kegiatan tidak berizin yang telah merusak lingkungan hidup bertahun-tahun.

Ketiga, isi Kebijakan Belum Disesuaikan Dengan Peralihan Kewenangan Bidang Pertambangan dan Kehutanan Yang Diatur oleh UU No 23 Tahun 2014 Tentang Pemerintahan Daerah. Peralihan kewenangan ini juga membuat adanya kebijakan yang dicabut. Kebijakan yang dicabut tentu mengenai pertambanagan dan kehutanan. Ini tentu tidak sejalan dengan fakta yang menyatakan bahwa kerusakan lingkungan hidup di Dharmasraya dan Sijunjung banyak terjadi pada bidang pertambangan dan kehutanan. Maka dari itu Hal ini berdampak akan menyulitkan dalam mencapai kebijakan pengelolaan lingkungan hidup yang optimal.

\footnotetext{
${ }^{18}$ Wawancara dengan Walbandi, Wakil Ketua DPRD Kabupaten Sijunjung, di Kantor DPRD Sijujung, Pada tanggal 15 Agustus 2019
} 


\section{Pengaruh Peralihan Kewenangan Bidang Pertambangan dan Kahutanan Terhadap Kebijakan Lingkungan Hidup di Daerah}

Dari peralihan kewenangan ini ternyata berpengaruh terhadap jalannya kebijakan lingkungan hidup yang ada di daerah. Pertama, perubahan Kebijakan di Tingkat Kabupaten. Kedua, kebijakan lingkungan hidup yang tidak optimal di Kabupaten. Peralihan kewenangan pada UU No 23 Tahun 2014 tentang Pemerintahan Daerah membawa sejumlah pengaruh pada proses kebijakan lingkungan hidup di Kabupaten. Pengaruh ini dapat terlihat dari Rumusan kebijakan yang sudah tidak memuat pertambangan dan kehutanan lagi di dalamnya. Peralihan kewenangan ini membuat adanya kebijakan yang dicabut. Kebijakan yang dicabut tentu mengenai pertambangan dan kehutanan. Ini tentu tidak sejalan dengan fakta yang menyatakan bahwa kerusakan lingkungan hidup di Dharmasraya banyak terjadi pada bidang pertambangan dan kehutanan. Maka dari itu Hal ini berdampak akan menyulitkan dalam mencapai kebijakan pengelolaan lingkungan hidup yang optimal.

Kabupaten Sijunjung telah membuat sejumlah penyesuaian, namun penyesuaian yang baru dilakukan hanya sebatas administratif saja. Hal ini terjadi karena adanya kesulitan dalam hal implementasi. Hal yang sama juga terjadi di Kabupaten Dharmasraya. Keempat, Pengawasan perusakan lingkungan hidup pada sektor pertambangan dan kehutanan menjadi tidak jelas. Dari pemaparan diatas dapat dilihat adanya kekosongan kewenangan yang tidak bisa disentuh Pemerintahan Kabupaten. Kekosongan tersebut menghambat pekerjaan untuk menyelesaikan atau mengurusi urusan lingkungan hidup. Kekosongan tersebut salah satunya dalam melakukan pengawasan. Kebijakan lingkungan hidup di Kabupaten Sijunjung dan Kabupaten Dharmasraya terlihat tidak optimal karena adanya kekosongan wewenang dari segi pengawasan. Penegakan hukumpun hanya dilakukan oleh kepolisian saja dan itu bergerak dalam bidang penertiban aktivitas ilegal yang diatur dalam UU. Namun, pengaruh seperti ini tidak bisa dibiarkan begitu saja. Pemerintahan Kabupaten sudah jelas punya wewenang terkait lingkungan hidup. Wewenang tersebut haruslah tetap dikerjakan dan pemerintahan kabupaten tidak lepas tangan untuk urusan tersebut.

\section{KESIMPULAN}

Dari hasil interpretasi data yang telah peneliti lakukan berdasarkan dari hasil penelitian di bab-bab sebelumnya maka peneliti menarik kesimpulan sebagai berikut:

1. Analisis isi kebijakan publik ini menunjukkan bahwa Kabupaten Sijunjung dan Kabupaten Dharmasaraya telah sama-sama meletakkan permasalahan kerusakan lingkungan hidup sebagai sebuah masalah publik. Hingga masalah tersebut direspon dengan mengeluarkan sejumlah peraturan. Namun, setelah dianalisis isi 
kebijakan tersebut ternyata hanya menjelaskan mengenai pengelolaan lingkungan hidup secara umum dan belum memuat secara mendalam mengenai pemecahan masalah terhadap kerusakan lingkungan hidup yang terjadi.

2. Evaluasi isi kebijakan yang dilakukan sesuai dengan kriteria menurut William $\mathrm{N}$ Dunn yakni efektivitas dan ketepatan. Dari evaluasi ini dapat dilihat bahwa kebijakan pengelolaan lingkungan hidup di kedua Kabupaten tersebut belum memuat perencanaan dalam menghadapi kegiatan merusak lingkungan hidup yang telah bertahun-tahun lalu dilakukan dan kebijakan yang ada hanya bertumpu pada pencegahan belum pada pemulihan.

3. Peralihan kewenangan pada sektor Pertambangan dan kehutanan mempengaruhi terhadap jalannya kebijakan lingkungan hidup di tingkat Kabupaten. Pengaruh tersebut dapat berupa perubahan kebijakan di tingkat kabupaten, kebijakan lingkungan hidup yang tidak optimal di kabupaten, kesulitan berkoordinasi hingga pengawasan kerusakan lingkungan hidup pada sektor pertambangan dan kehutanan menjadi tidak jelas.

\section{DAFTAR PUSTAKA}

Abdulrahman, Syahid. 2016. "Konflik Kepentingan Kelompok Masyarakat dan Lembaga Negara (Studi Kasus: Konflik dalam penertiban Tambang Emas Di Jorong Aur Jaya, Nagari Koto Padang, Kabupaten Dharmasraya Pada Tahun 2012)". Skripsi.Padang: Universitas Andalas.

Agustino, Leo. 2008.Dasar- dasar Kebijakan Publik. Bandung: Alfabeta.

Ahyani. 2011. Tesis: "Pengaruh Kegiatan Pertambangan Emas Terhadap Kondisi Kerusakan Tanah Pada Wilayah Pertambangan Rakyat Di Bombana Provinsi Sulawesi Tenggara”. Semarang: Universitas Diponegoro.

Arikonto, Suharsimi. 2005. Manajemen Penelitian (edisi Revisi). Jakarta: Rineke Cipta.

Bisnis.com, Imbangi Alih Fungsi Lahan, Sumbar Cetak 1.000 Ha SawahBaru, diakses di (https://ekonomi.bisnis.com/read/20140213/99/203019/imbangi-alih-fungsi-lahansumbar-cetak-1.000-ha-sawah-baru)

Bungin, Burhan. 2003. Analisis Data Penelitian Kualitatif. Jakarta: Raja Grafindo Persada.

Cendana news, Warga Sijunjung cemas lahan swah jadi tambang, diakses di (https://www.cendananews.com/2018/04/warga-sijunjung-resah-lahan-sawah-jaditambangemas.html) 
Cnn Indonesia, Maraknya Penambangan Liar Perparah Kerusakan Lingkungan diakses di (https://www.cnnindonesia.com /nasional/20160602095858-20135269/maraknyapenambangan-liar-perparah-kerusakan-lingkungan)

Dewi Anggraini. 2016. "Respon Pemerintahan Daerah Terhadap Aktivitas Tambang Emas Ilegal Di Kabupaten Sijunjung Pasca Lahirnya Undang-Undang No. 23 Tahun 2014". Padang: Univeristas Andalas.

Dunn, William. 2003.Pengantar Analisis Kebijakan Publik. Yogyakarta: Gadjah Mada University Press.

Elant Firdaus. 2019. "Pengawasan Pemerintah Daerah Dalam Kegiatan Penambangan Emas Tanpa Izin Di Kabupaten Dharmasraya”. Skripsi. Padang: Universitas Andalas.

Haluan, Tambang Liar Cemari Batangharidiakses di (https://www.harianhaluan. com/news/detail/56269/tambang-liar-cemari-batanghari)

Instagram KKI WARSI @KKI_Warsi

Islamy, Irfan. 2009. Prinsip- prinsip Perumusan Kebijaksanaan Negara. Jakarta: Bumi Aksara.

2010. Kebijakan Publik. Jakarta: Universitas Terbuka.

Kompas.com, 70 Persen Kerusakan Lingkungan akibat OperasiTambang diakses di (https://regional.kompas.com/read/2012/09/28/17313375/70.Persen.Kerusakan.Ling kungan.akibat.Operasi.Tambang)

Moleong, Lexy J. 2004. Metode Penelitian Kualitatif. Bandung: Remaja Rosda Karya.

Mongabay, Catatan dari Sumbar: Dari soal Deforestasi, sampai Hak Kelola Rakyat diakses di (https://www.mongabay.co.id/2017/12/31/catatan-dari-sumbar-dari-soaldeforestasi-sampai-hak-kelola-rakyat)

Nawawi, Hadari dan M. Martini Hadari. 1992. Instrumen Penelitian Bidang Sosial.Yogyakarta: Gadjah Mada University Press.

Nazir, Moh. 2003. Metode Penelitian. Jakarta: Ghalia Indonesia.

Putra, Mido. 2016. Kebijakan Pemerintah Kebupaten Kuantan Singingi Dalam Pengendalian Kerusakan Lingkungan Hidup Akibat Pertambangan Emas Tanpa Izin (Peti). Jurnal Jom Fisip.3( 2).

Siahaan, N.H.T. 2004. Hukum Lingkungan Dan Ekologi Pembangunan. Jakarta: Erlangga.

Soemarwoto, Otto. 2001. Analisa Mengenal Dampak Lingkungan. Yogyakarta: UGM Press.

Sugiyono. 2005. Memahami Penelitian Kualitatif. Bandung : CV Alfabeta. 
JDPL (Jurnal Demokrasi dan Politik Lokal)

Vol. 2 No. 1, April 2020

E-ISSN : 2721-3730

P-ISSN : 2656-5439

2010. Metode penelitian Kuantitatif Kualitatif dan R\&D. Bandung: Penerbit Alfabeta.

Tangkilisan, Hesel Nogi. 2003. Kebijakan Publik Yang Membumi. Yogyakarta: Lukman Offset YPAPI.

Winarno, Budi. 2002. Teori dan Proses Kebijakan Publik. Yogyakarta: Media Pressindo. 